\title{
Role of reactive oxygen species (ROS) scavengers on plant growth and shelf life of Tomato
}

\author{
Md Atiqur Rahman, AZM Shafiullah Prodhan* and Sheikh Shah Asadullah Salehin \\ Department of Horticulture, Bangabandhu Sheikh Mujibur Rahman Agricultural University, Gazipur, Bangladesh
}

*Corresponding author: AZM Shafiullah Prodhan,Department of Horticulture, Bangabandhu Sheikh Mujibur Rahman Agricultural University, Bangladesh

\begin{abstract}
Tomato is widely cultivated and important nutritious vegetable in the world. It deteriorates rapidly after harvesting. High reactive oxygen species (ROS) level has negative effect on growth and development through oxidative stress by affecting physiological and molecular processes. Oxidative stress can be recovered by the scavenging system which consists of enzymatic as well as nonenzymatic antioxidants. So, ROS balance and antioxidant are necessary for better growth and prolong shelf life. As an antioxidant ascorbic acid was applied several times which played key role for plant growth and stress management. This study evaluated the role of ascorbic acid on physical and physiological changes of tomato. A marked variation was observed on some parameters regarding leaf length, panicle length, flower cluster and fruits per plant, chlorophyll content, MDA content, fruit yield per plant etc. Application of ascorbic acid increased leaf length, chlorophyll content, dry matter and decreased MDA content. Flower cluster per plant as well as panicle length was maximum at 45 DAT. Number of fruits and fruit yield/plant was fluctuated slightly with the application of ascorbic acid. Thus antioxidant has played a pivotal role on growth and development of plant.
\end{abstract}

Keywords: Horticulture; radio molecule; plant stress; stress combination; plant growth regulator

\section{Introduction}

Tomato (Lycopersicon esculentum) is used as edible vegetables belong to the family solanaceae in the world. Nutritive value of the fruit is an important aspect of quality in tomato. Tomato is usually treated as common food due to its minerals, vitamins, few antioxidants, essential amino acids, sugars as well as dietary fibers that are important ingredients for culinary and chutney, pickles, soup, juice, and puree [1]. It contains few major chemical elements such as $2.50-4.50 \%$ sugar, $15-20 \mathrm{mg} / 100 \mathrm{~g}$ vitamin $\mathrm{C}, 0.25-0.50$ $\mathrm{g} / 100 \mathrm{~g}$ calcium (Ca), 0.10-0.50g/100g magnesium (Mg), 0.20-0.80 $\mathrm{g} / 100 \mathrm{~g}$ phosphorous, and lycopene 20-50 g/100g [2]. Tomato is cultivated across Bangladesh as its adaptation to any type of soil and environment $[3,4]$. Tomato is an extremely perishable fruit and rapidly deteriorates after ripening [5]. Post-harvest degradation that accounts for tremendous financial losses of more than 25 percent of fresh tomato per year is a major challenge for tomato cultivation [6-8].
It is commercially cultivated in Bangladesh as well as in many countries around the world for its taste and nutritional status [9-11]. In Bangladesh, it is cultivated as winter vegetable with annual production of about 389000 metric tons [12]. The popular cultivation areas of tomato in Bangladesh include Chittagong, Comilla et al. [13-15]. However, tomatoes are grown extensively all over the country. In Bangladesh, tomato is mainly grown in the winter season [16]. November to February is the congenial period for tomato cultivation in Bangladesh $[17,18]$.

Plants use 02 to generate the required energy for their own production processes. Land state $\mathrm{O} 2$ is reduced to water $(\mathrm{H} 2 \mathrm{O})$ and ROS during normal cellular metabolism that include $\mathrm{O}^{-}, \mathrm{H} 2 \mathrm{O} 2, \mathrm{OH}-$ and $02[19,20]$. Reactive oxygen species (ROS), like 02, H2O2, 02and $\mathrm{HO}$, are highly reactive molecules, causing protein, DNA, and lipid oxidative damage [21-23]. In addition to being toxic molecules, however, ROS also plays a role of signaling molecules which regulate 
many important biological processes [24-26]. Since ROS plays a dual role in plants, both as key regulators for growth, development and defense pathways and as toxic aerobic metabolism by-products [27-29].

The accretion of ROS is allied with growth and over maturation of the fruit [29]. The high ROS levels are harmful for cells of plant and equilibrium between ROS growth and scavenging [30-31]. The fruit undergoes photosynthesis and respiration during the early expansion stages, as well as other physiological processes to satisfy its size expansion requirements [32-34]. ROS is produced and accumulated during these processes [35]. The application of antioxidant compounds after harvest will effectively prolong the shelf-life of tomatoes [36]. Extending the shelf-life by minimizing ROS in other crops has also proved successful. Tomato fruit ripening and over-ripening is difficult. It requires numerous changes in chemical and morphological words. The functions of antioxidants and scavenging process studied widely across all these modifications [37, 38]. The fruit antioxidant system's scavenging capacity decreases during ripening and over-ripening [39]. The main factor controlling tomato fruit ripening and overripening is the balance between antioxidant activity and ROS generation [40]. Different strategies were used to prolong the shelf life. The simplest and commonly practiced is to collect tomato in green stage as well as store it at minimum temperature [41]. The fruits are subsequently subjected to ethylene to cause ripening [42]. Therefore, this study aims to determine the suitable stage of antioxidant application to lower the ROS level in plants as well as in fruits. Hence, this experiment intended to assess the effectiveness of various treatments on plant growth of tomato and increase the shelf life of tomato.

\section{Materials and Methods}

This study was done in the horticulture experimental field and Horticulture lab, BSMRAU campus, Gazipur, Bangladesh during November 2018 to April 2019. Randomized Complete Block Design (RCBD) was monitored for this experiment with 3 replications. 30 days old seedlings of tomato were collected and transplanted in main field on 20 November 2018 following $60 \mathrm{~cm}$ x $50 \mathrm{~cm}$ plot spacing in $2.4 \mathrm{~m} \times 2.5 \mathrm{~m}$ zize plot. There were four rows in each plot having four plants/row and 16 plants were accumulated in each plot. The tomato seeds (BARI tomato 14) were obtained from the department of Horticulture, BSMRAU, Gazipur for experimental purpose.

Treatments for the growth parameter of the tomato are as follows:

$$
\begin{aligned}
\mathrm{T} 1 & =\text { Control (Water) } \\
\mathrm{T} 2 & =0.5 \mathrm{mM} \text { AsA } \\
\mathrm{T} 3 & =2 \mathrm{mM} \text { AsA } \\
\mathrm{T} 4 & =4 \mathrm{mM} \text { AsA }
\end{aligned}
$$

\section{Preparation and application of ascorbic acid}

Ascorbic acid was applied at 3, 4, 5and 6 weeks after transplanting. In control plot only distilled water was used. To prepare $0.5 \mathrm{mM}, 2 \mathrm{mM}, 4 \mathrm{mM}$ of AsA solution, laboratory grade chemical reagent was used. The stock solution was then preserved in glass jars at $40 \mathrm{C}$ in a refrigerator for preparing solutions with desired concentrations.

$\mathrm{V} 1 \mathrm{~S} 1=\mathrm{V} 2 \mathrm{~S} 2$

V1 =Volume of the stock solution needed

V2= Volume of the desired solution to be prepared

S1 = Strength of the stock solution

$\mathrm{S} 2=$ Strength of the desired solution to be prepared

Then ascorbic acid concentration was applied four times at 4 days interval. The first AsA application was done at the panicle initiation stage.

\section{Data Collection}

Data were collected from 5 plants that were selected randomly of each replication of whole treatments that separately on the following parameters in each unit plot. Seedlings leaf length was measured from every replication with measuring scale and the average was considered as leaf length. Panicle length of seedlings from each replication was measured with measuring scale and the average was considered as leaf length. Flower cluster of plants from each replication was recorded and average was calculated and considered as fruit yield/plant. Total fruit yield of plants from each replication was recorded and average was calculated and considered as fruit yield/plant.

Dry matter (\%) was estimated by using the following formula:

$\%$ Dry matter $=($ Dry weight $) /($ Fresh weight $) \times 100$

\section{MDA content Measurement}

Fresh leaf samples (0.2) pounded in $5 \mathrm{ml}$ of 0.1 percent trichloroacetic acid (TCA) as well as centrifuged at 14,000 rpm for $15 \mathrm{~min} .1 \mathrm{ml}$ of the supernatant was blended in 20 per cent TCA with $2.5 \mathrm{ml} 0.5$ per cent TBA that incubated for $30 \mathrm{~min}$ in hot water $(95$ $\left.{ }^{\circ} \mathrm{C}\right)$ after centrifugation. Another centrifugation was done for 30 min at 10,000 rpm immediately after cooling from previous stage. Content of total chlorophyll was obtained from $200 \mathrm{mg}$ leaf tissues by following proper procedures. The UV visible spectrophotometer at 663 and $645 \mathrm{~nm}$ was used to record the absorbance.

\section{Data Analysis}

The observation (data) for various growth and yield contributing factors analyzed statistically to explore the mentionable variation obtained from the treatments of the experiment. Statistic 10 program used to examine the collected data. 


\section{Results and Discussion}

The results of different parameters that obtained from the present experiment have been presented and explained in this chapter. Data on different parameters were analyzed statistically and the results have been presented in different tables and figures. The result of each parameter has been explained and possible interpretations have been made in this section.

\section{Leaf Length $(\mathrm{cm})$}

There was little difference found in the leaves length of tomato during 1 month and 2 months after transplantation due Table 1: Effect of antioxidant on leaf length of tomato to application of different treatments (Table 1). The longest leaf length $(13.667 \mathrm{~cm})$ was recorded in $\mathrm{T} 4$ and the lowest leaf length $(13.33 \mathrm{~cm})$ was observed in $\mathrm{T} 2$ at 30 days after transplanting (DAT). In case of 60 days after transplanting, the highest leaf length $(37.90$ $\mathrm{cm})$ was observed in T2 and the lowest leaf length $(35.44 \mathrm{~cm})$ was found in $\mathrm{T} 1$ treatment. At 45 days after transplanting, different treatments showed statistically significant variation in the leaves length. The longest leaf length $(33.11 \mathrm{~cm})$ was recorded from T4 treatment while small leaf length $(28.44 \mathrm{~cm})$ was found in $\mathrm{T} 1$ treatment. This might be due to application of antioxidant reducing ROS content of leaves which helps to extend leaves length [43].

\begin{tabular}{|c|c|c|c|}
\hline \multirow{2}{*}{ Treatments } & \multicolumn{3}{|c|}{ Leaf length (cm) at different days after transplanting } \\
\cline { 2 - 4 } & 30 DAT & 45 DAT & 60 DAT \\
\hline $\mathrm{T}_{1}$ & $13.56 \mathrm{a}$ & $28.44 \mathrm{c}$ & $35.44 \mathrm{a}$ \\
\hline $\mathrm{T}_{2}$ & $13.33 \mathrm{a}$ & $30.22 \mathrm{bc} \mathrm{a}$ \\
\hline $\mathrm{T}_{3}$ & $13.44 \mathrm{a}$ & $31.89 \mathrm{ab}$ & $35.78 \mathrm{a}$ \\
\hline $\mathrm{T}_{4}$ & $13.67 \mathrm{a}$ & $33.11 \mathrm{a}$ & $35.89 \mathrm{a}$ \\
\hline LSD0.05 & 1.01 & 1.86 & 7.47 \\
\hline
\end{tabular}

Note: $5 \%$ level of probability. $\mathrm{T}_{1}=$ control, $\mathrm{T}_{2}=0.5 \mathrm{mM}, \mathrm{T}_{3}=2 \mathrm{mM}$ and $\mathrm{T}_{4}=4 \mathrm{mM}$.

\section{Panicle Length (cm)}

There was no significant variation in case of length of panicle (cm) during 1 month and 1.5 month after transplantation due to the application of antioxidant (Figure 1). The maximum length of panicle $(4.33 \mathrm{~cm})$ was recorded in $\mathrm{T} 1$ and the minimum length of panicle $(4.00 \mathrm{~cm})$ was recorded in $\mathrm{T} 4$ at 30 days after transplanting. At 45 DAT, the ranges varied from $11.00 \mathrm{~cm}$ to $11.44 \mathrm{~cm}$ where $\mathrm{T} 4$ gave the highest value $(11.00 \mathrm{~cm})$ and the lowest value $(11.44 \mathrm{~cm})$ was found in T1. Statistically significant variation was observed for panicle length at 60 days after transplanting. Among the different treatments the maximum value $(13.667 \mathrm{~cm})$ was found in $\mathrm{T} 3$ and $\mathrm{T} 4$ treatment which was significantly different from $\mathrm{T} 1(11.66 \mathrm{~cm})$. This might be due to the balance of network of ROS and antioxidant was higher at 60 days after transplanting.

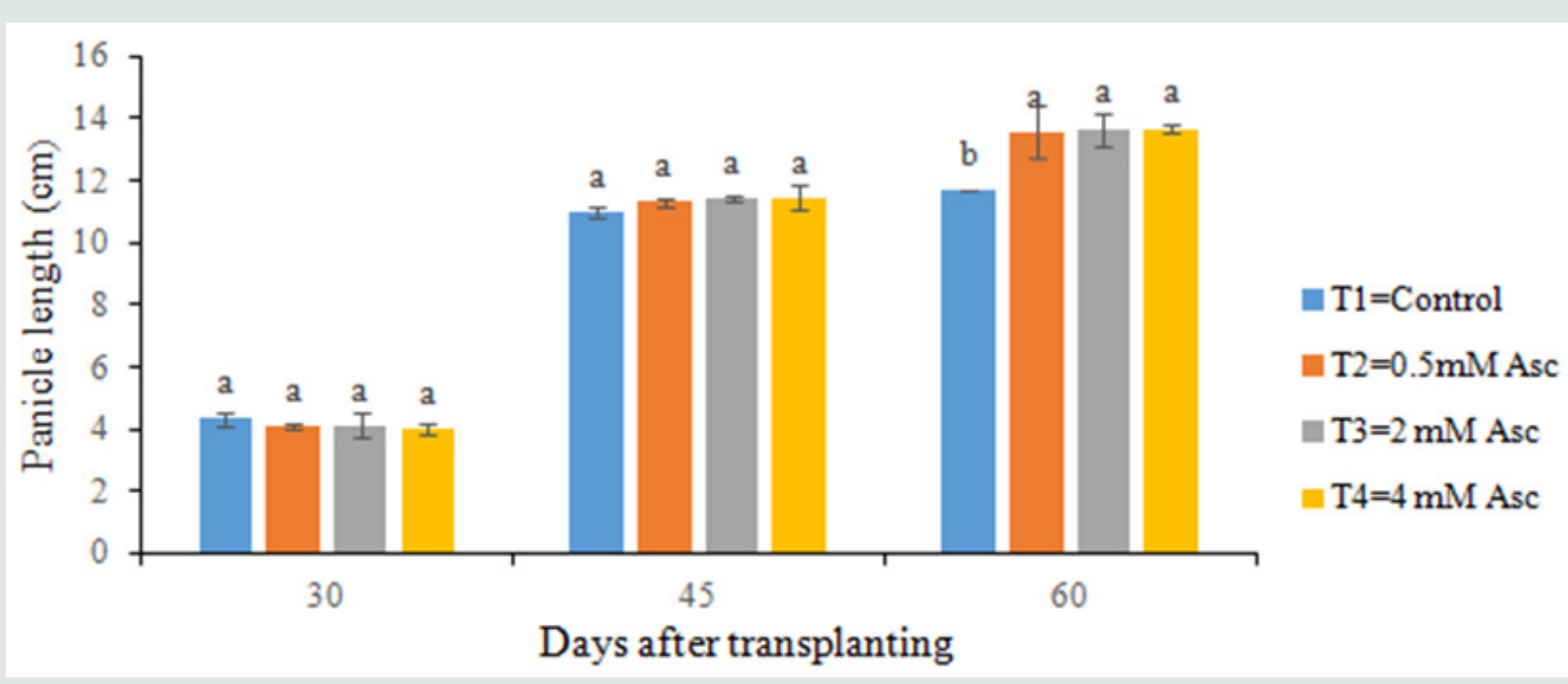

Figure 1: Effect of diverse doses of antioxidant on panicle length of tomato 


\section{Chlorophyll Content}

T4 scored the maximum chlorophyll content percentage (57.46\%), whereas the minimum chlorophyll content $(50.07 \%)$ was obtained from T1 at 30 days after transplanting (Figure 2). There was no remarkable variation in chlorophyll content of leaves at 45 days after transplanting (Figure 3). The maximum chlorophyll content percentage $(56.96 \%)$ recorded from T2 treated plants, while the minimum chlorophyll content (55.27\%) was found from T1 treated plants at 45 days after transplanting. Chlorophyll content of tomato varied significantly with the use of diverse doses of treatments at 60 days after transplanting (Figure 3). The maximum chlorophyll content percentage (64.07\%) obtained from $\mathrm{T} 4$ which is statistically similar with $\mathrm{T} 2$ and $\mathrm{T} 3$, while the minimum (57.60\%) recorded from $\mathrm{T} 1$.

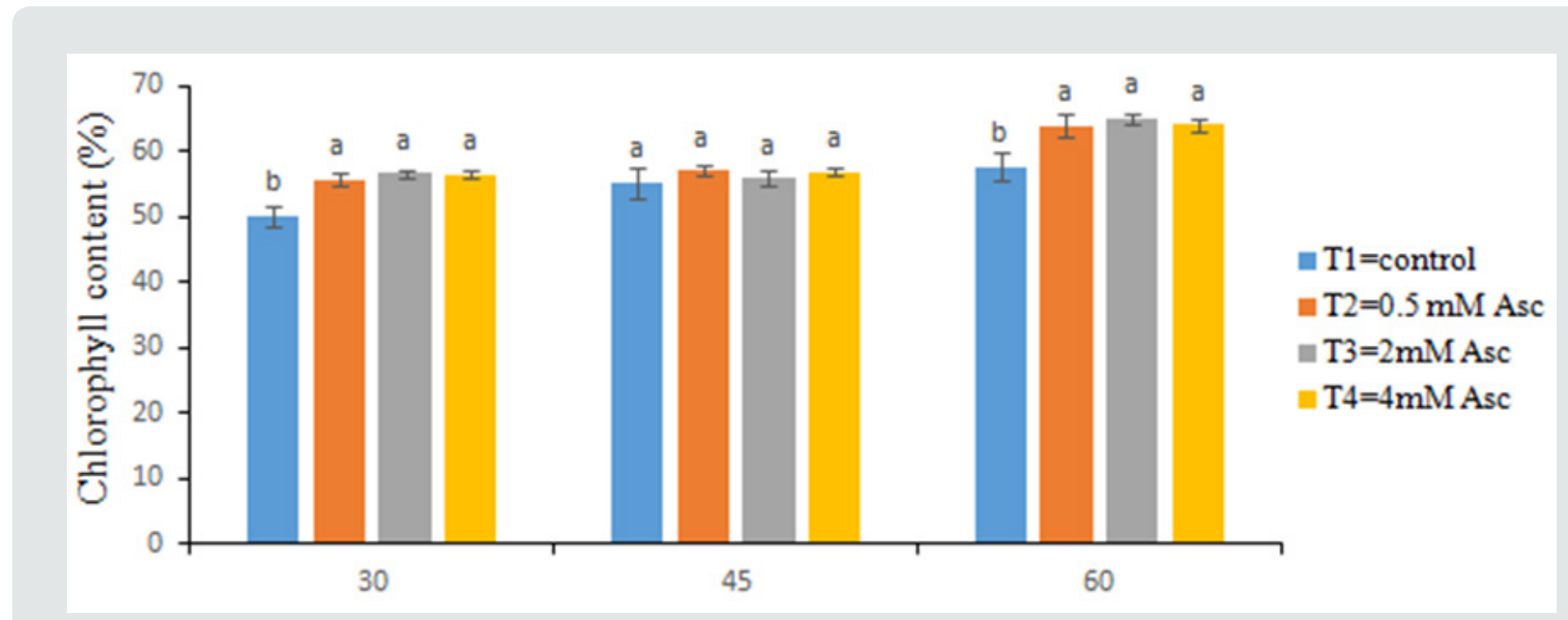

Figure 2: Chlorophyll content of tomato leaves
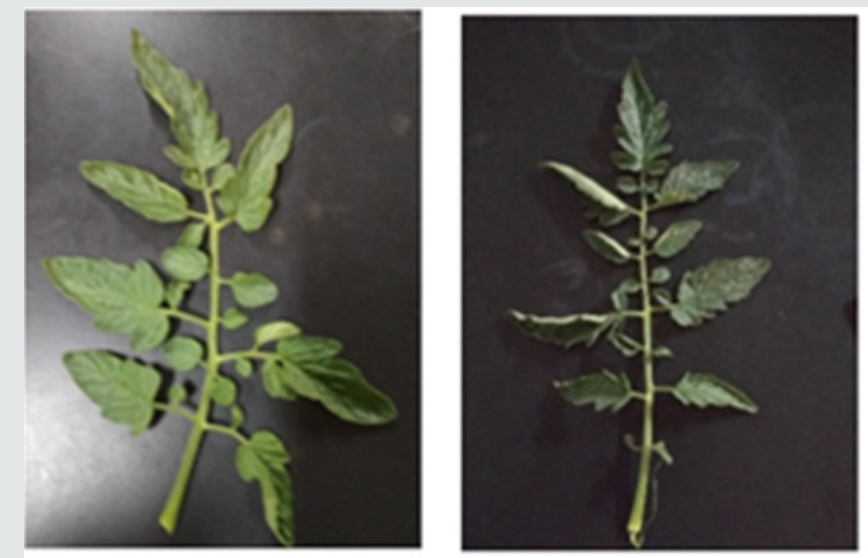

\section{Control}

$0.5 \mathrm{mM}$

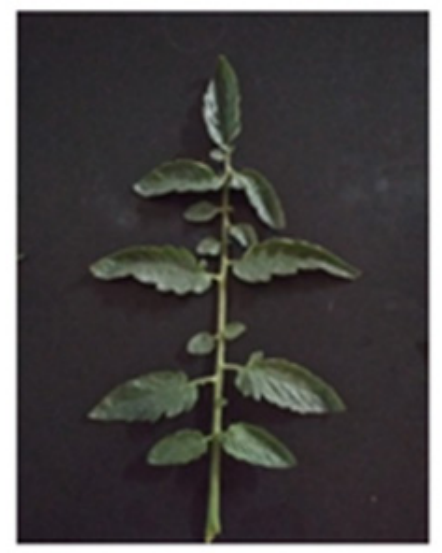

$2 \mathrm{mM}$

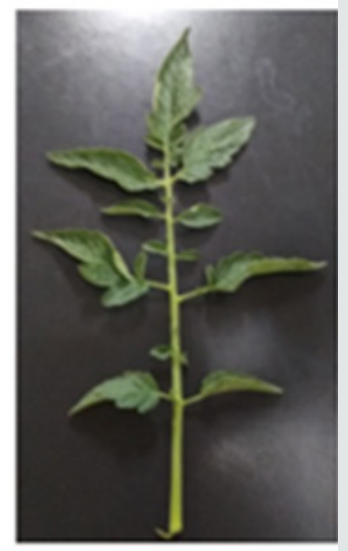

$4 \mathrm{mM}$

Figure 3: Tomato leaf after application of different doses antioxidant

\section{Flower Cluster per Plant}

Significant variation was found in the flower cluster per plant at 30 days and 60 days after transplanting (Table 2). The number of flower cluster per plant varied from 5.44 to 7.33 at 30 days after transplanting. The maximum flower cluster (7.33) per plant was produced in $\mathrm{T} 2$ and minimum flower cluster (5.44) per plant was observed in T4. At 45 days after transplanting, the maximum flower cluster (10.88) in every plant was recorded in $\mathrm{T} 4$ and the minimum flower cluster (8.22) in every plant was observed in T1. At 60 days after transplanting, flower cluster per plant varied slightly 
with each treatment and it varied from 13.66 to 15.66. It might be antioxidant is more effective at 45 DAT resulting in higher flower cluster per plant.

Table 2: Effect of antioxidant on flower cluster

\begin{tabular}{|c|c|c|c|}
\hline \multirow{2}{*}{ Treatments } & \multicolumn{3}{|c|}{ Flower cluster per plant at different days after } \\
transplantation \\
\cline { 2 - 4 } & $\mathbf{3 0 ~ D A T}$ & $\mathbf{4 5}$ DAT & 60 DAT \\
\hline $\mathrm{T}_{1}$ & $6.22 \mathrm{ab}$ & $8.22 \mathrm{~b}$ & $15.00 \mathrm{a}$ \\
\hline $\mathrm{T}_{2}$ & $7.33 \mathrm{a}$ & $10.67 \mathrm{a}$ & $15.33 \mathrm{a}$ \\
\hline $\mathrm{T}_{3}$ & $7.11 \mathrm{a}$ & $10.11 \mathrm{a}$ & $14.89 \mathrm{a}$ \\
\hline $\mathrm{T}_{4}$ & $5.44 \mathrm{~b}$ & $10.88 \mathrm{a}$ & $13.66 \mathrm{a}$ \\
\hline LSD0.05 & 1.55 & 1.62 & 3.68 \\
\hline
\end{tabular}

Note: $5 \%$ level of probability. $\mathrm{T}_{1}=$ control, $\mathrm{T}_{2}=0.5 \mathrm{mM}, \mathrm{T}_{3}=2 \mathrm{mM}$ and $\mathrm{T}_{4}=4 \mathrm{mM}$.

\section{Number of Fruits per Plant}

Data on 30 days, 45 days and 60 days after transplanting were recorded (Figure 3). At 30 days, the fruits/plant number ranged from 333 to 2.22 . The value 2.22 was produced in T3 treatment and the minimum number of fruits/plant (.333) was recorded in T1 treatment. At 45 days after transplanting, all of the treatments were statistically similar where the maximum fruits/plant number (29.55) were in T2 and the minimum fruits/plant (27.11) were in T3. At 60 days after transplanting, the number of fruits was varied among treatments. Fruits/plant ranged from 43.55 to 56.00. 56 fruits/plant were produced in T2 treatment and the low number of fruits/plant (43.55) was obtained in T4 treatment.

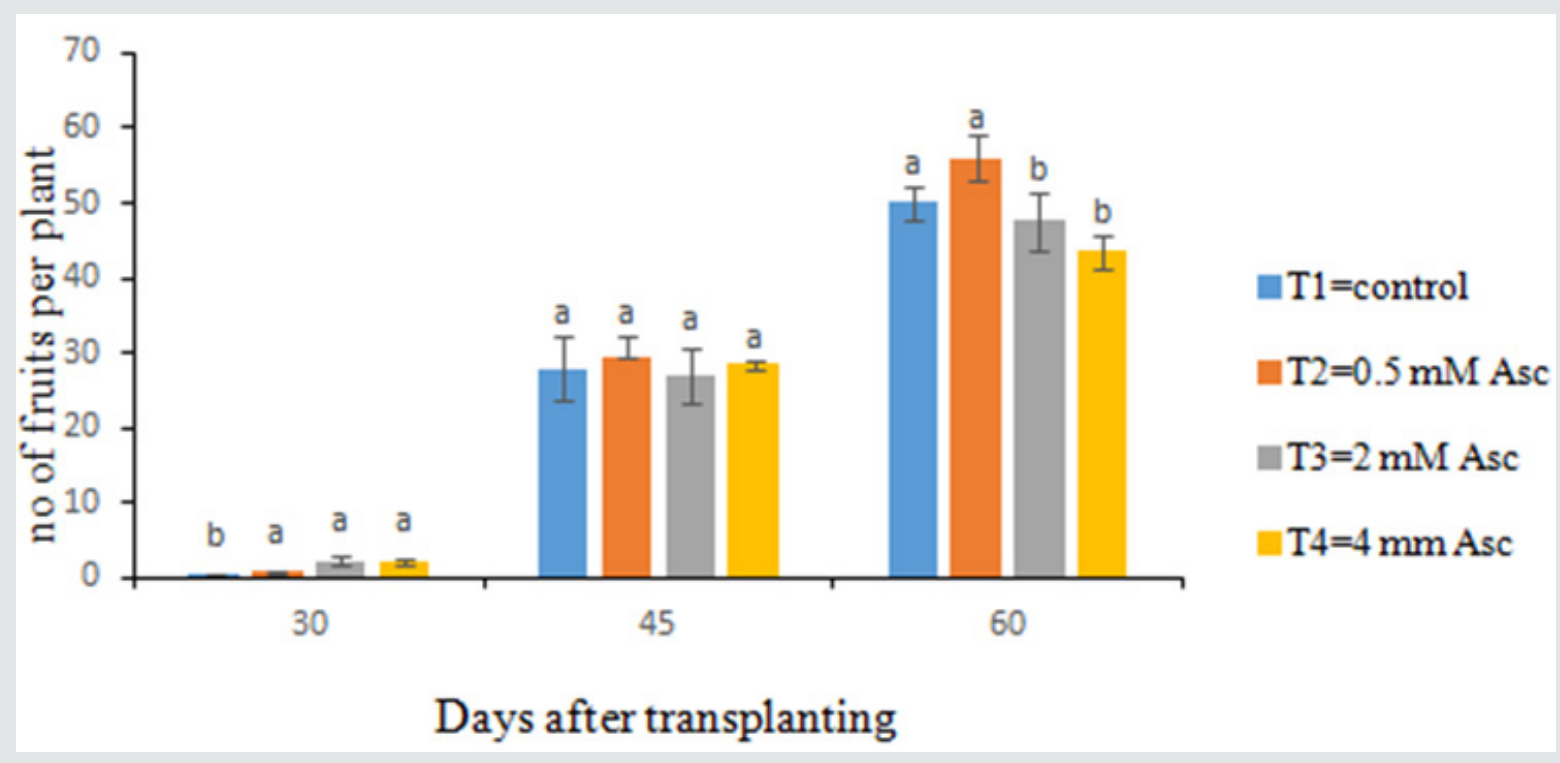

Figure 3: Outcome of different doses of antioxidant

\section{MDA in Leaves}

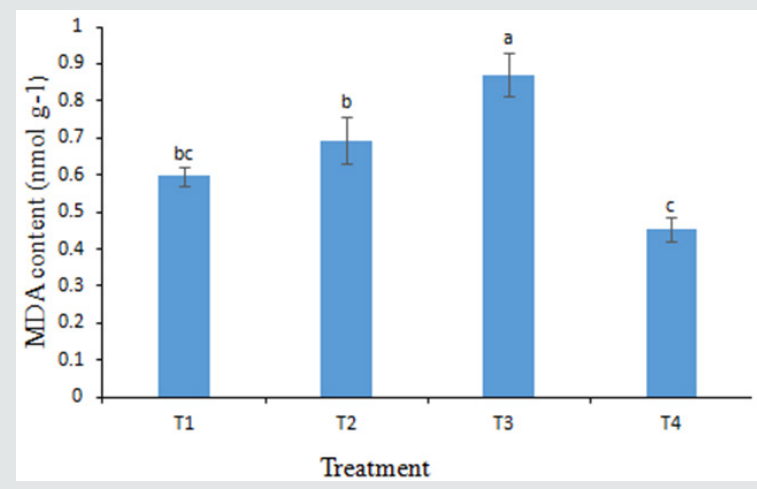

Figure 4: Outcome of different doses of antioxidant
Significant variation of MDA was observed among the treatments (Figure 4). Oxidative damage to leaf lipids, resulting from stress expressed as MDA. The maximum MDA (0.871 nmol g1) was obtained in T3 treatment which was statistically significant with all other treatments. The lowest MDA (0.4537 nmol g1) was observed in $\mathrm{T} 4$ treatment. It might be $\mathrm{T} 4$ are more effective to lower the MDA content due to growing environment [44].

\section{Fruit Yield per Plant}

A large disparity in fruit yield among the four treatments was found (Table 3). Fruit weight of different treatments ranged from $2.372 \mathrm{~kg}$ to $2.851 \mathrm{~kg}$. The maximum fruit weight $(2.851 \mathrm{~kg})$ obtained in $\mathrm{T} 2$ and the lowest fruit weight $(2.372 \mathrm{~kg})$ was obtained from the $\mathrm{T} 4$. 
Table3:Outcomeofdiversedosesofantioxidantonfruityield/plant

\begin{tabular}{|c|c|}
\hline Treatment & Fruit yield (kg) \\
\hline $\mathrm{T}_{1}$ & $2.737 \mathrm{a}$ \\
\hline $\mathrm{T}_{2}$ & $2.851 \mathrm{a}$ \\
\hline $\mathrm{T}_{3}$ & $2.640 \mathrm{ab}$ \\
\hline $\mathrm{T}_{4}$ & $2.372 \mathrm{~b}$ \\
\hline LSD0.05 & 0.31 \\
\hline
\end{tabular}

Note: $5 \%$ level of probability. $\mathrm{T}_{1}=$ control, $\mathrm{T}_{2}=0.5 \mathrm{mM}, \mathrm{T}_{3}=2 \mathrm{mM}$ and $\mathrm{T}_{4}=4 \mathrm{mM}$.

\section{Dry Matter}

The result revealed that there was a significant variation among the treatments (Figure 5). The highest dry matter (7.22\%) in tomato was recorded from $\mathrm{T} 4$ treatment whereas the minimum dry matter (5.85\%) was observed in T1 treatment where no antioxidant was applied.

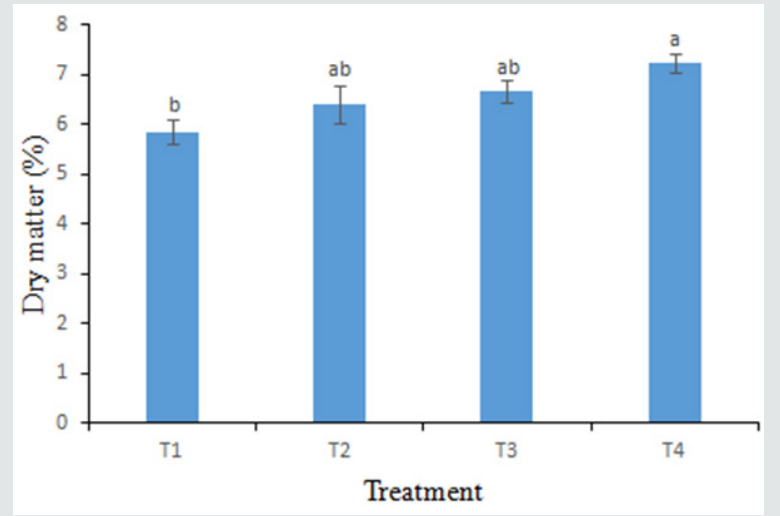

Figure 5: Effect of different doses of antioxidant on MDA content of tomato leaves

\section{Leaf Chlorophyll}

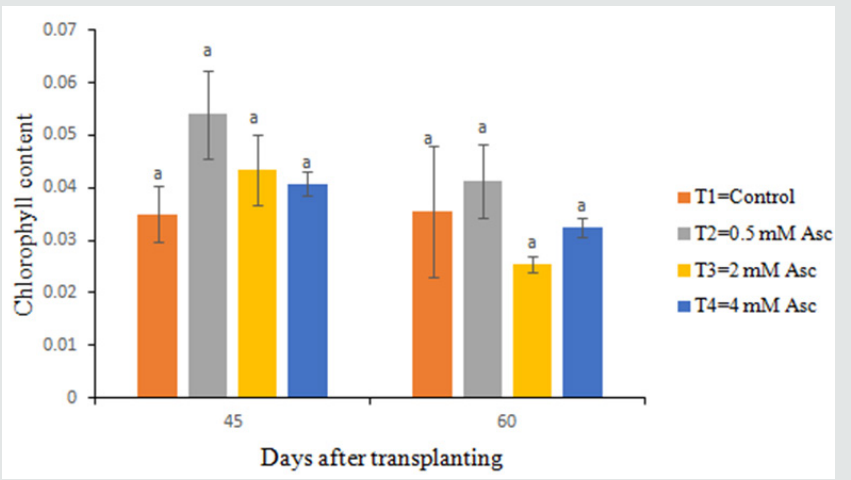

Figure 6: Consequence of diverse doses of antioxidant on chlorophyll content of tomato leaves
Though chlorophyll content of leaves did not show significant variations among the treatments, the range of chlorophyll content of tomato varied (Figure 6). At 45 days after transplanting, the highest value $(.0540 \mathrm{~nm})$ was recorded in $\mathrm{T} 2$ and lowest value $(.035$ $\mathrm{nm}$ ) was found in $\mathrm{T} 1$ treatment. At 60 days after transplanting, the maximum value $(.04 \mathrm{~nm})$ was found in $\mathrm{T} 2$ and minimum value $(.026 \mathrm{~nm})$ was found in T3 treatment.

\section{Physiological changes involving in shelf-life of tomato}

\section{Malondialdehyde (MDA) content}

A statistically significant variation was observed in MDA of tomato fruit at storage for different treatments (Table 4). At 0 minutes, the highest MDA (1.52 nmol g1) was obtained in T2 treatments and the lowest MDA (0.73 nmol g1) was found in T4 treatments. At 15 minutes, the highest MDA (1.6989 nmol g1) was obtained in T1 whereas the lowest MDA (1.06 nmol g1) was obtained in T4. At 30 minutes, the highest MDA (1.98 nmol g1) was found in T2 whereas the lowest MDA (1.34 nmol g1) value recorded in T1 which is closest to T2, T3. Lower MDA content indicates lesser amount of stress condition which helps to delay ripening. Furthermore, the fruits which contain high MDA enhance ripening due to stress condition.

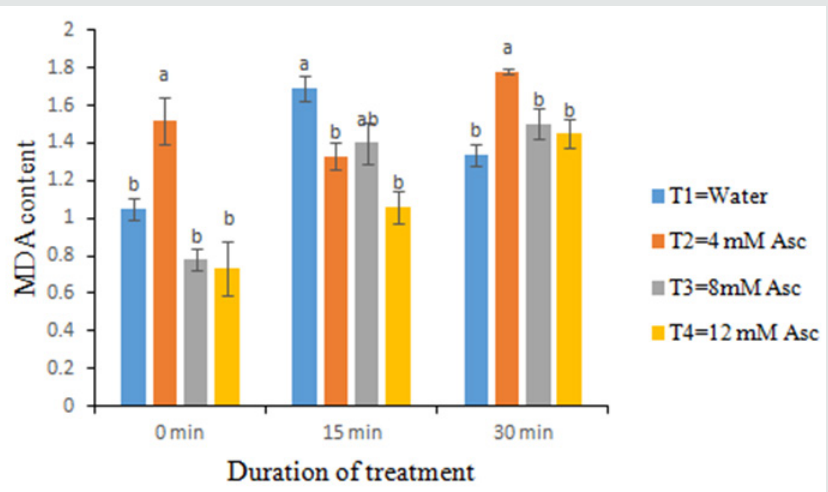

Figure 7: Consequence of diverse doses of antioxidant on chlorophyll content of tomato leaves

\section{Chlorophyll Content}

Significant variation was recorded in chlorophyll content of stored tomato fruit with diverse doses of treatment (Table 4). At 0 minutes, the highest value of chlorophyll $(2.71 \mu \mathrm{g} / \mathrm{g})$ was recorded in $\mathrm{T} 3$ and the lowest value $(0.011 \mu \mathrm{g} / \mathrm{g})$ was recorded in T4 treatment. At 15 minutes, the highest chlorophyll (4.78 $\mu \mathrm{g} / \mathrm{g})$ was recorded in T3 whereas the lowest value $(1.28 \mu \mathrm{g} / \mathrm{g})$ was found in T1. At 30 minutes, the maximum value of chlorophyll $(5.26 \mu \mathrm{g} / \mathrm{g})$ was found in T2 treatment and minimum chlorophyll $(1.49 \mu \mathrm{g} / \mathrm{g})$ was recorded in T1. Tomato fruits with high chlorophyll content indicate its longer shelf life whereas low chlorophyll content shows shorter shelf life. 
Table 4: Chlorophyll content $(\mu \mathrm{g} / \mathrm{g})$ of stored tomato fruit influenced by different doses of antioxidant

\begin{tabular}{|c|c|c|}
\hline \multirow{2}{*}{ Treatments } & \multicolumn{2}{|c|}{$\begin{array}{c}\text { Chlorophyll content }(\mu \mathrm{g} / \mathrm{g}) \text { at different } \\
\text { duration }\end{array}$} \\
\cline { 2 - 3 } & $\mathbf{0 ~} \mathbf{~ m i n}$ & $\mathbf{1 5} \mathbf{~ m i n}$ \\
\hline $\mathrm{T}_{1}$ & $.021 \mathrm{bc}$ & $1.28 \mathrm{~b}$ \\
\hline $\mathrm{T}_{2}$ & $1.56 \mathrm{ab}$ & $1.96 \mathrm{~b}$ \\
\hline $\mathrm{T}_{3}$ & $2.71 \mathrm{a}$ & $4.78 \mathrm{a}$ \\
\hline $\mathrm{T}_{4}$ & $.011 \mathrm{c}$ & $1.82 \mathrm{~b}$ \\
\hline LSD0.05 & 2.23 & 0.884 \\
\hline
\end{tabular}

Note: $5 \%$ level of probability. $\mathrm{T}_{1}=$ control, $\mathrm{T}_{2}=4 \mathrm{mM}, \mathrm{T}_{3}=8 \mathrm{mM}$ and $\mathrm{T}_{4}=12 \mathrm{mM}$

(Table 4) Chlorophyll content ( $\mu \mathrm{g} / \mathrm{g}$ ) of stored tomato fruit influenced by different doses of Conclusion

Application of antioxidant played an important role on growth and physiologically changes involving shelf life of tomato. Different concentrations of antioxidant significantly influenced most of the recorded characters. The maximum leaf length was recorded 13.67 $\mathrm{cm}$ at 30 days after transplanting and $33.11 \mathrm{~cm}$ at 45 DAT in T4 treatment where $4 \mathrm{mM}$ ascorbic acid was applied. The lowest leaf length was recorded $28.44 \mathrm{~cm}$ at 45 DAT and $35.44 \mathrm{~cm}$ at 60 DAT from $\mathrm{T} 1$ treatment where no antioxidant was applied. In case of panicle length, the maximum panicle length also observed from T4 treatment at 45 DAT and 60 DAT was $11.00 \mathrm{~cm}$ and $13.667 \mathrm{~cm}$ respectively whereas lowest panicle length was observed in $\mathrm{T} 1$ where no antioxidant was applied. Chlorophyll content measured by SPAD value showed the highest value $(57.46 \%$ and $64.067 \%)$ in T4 treatment at 30 DAT and 60 DAT respectively, while the lowest value found in T1 at different DAT. Lowest MDA (0.4537 nmol g1) in leaves was measured in T4 treatment which was statistically significant from other treatment. Statistically significant variation was observed in MDA and chlorophyll content of stored tomato fruit for different treatments. Comparatively lowest MDA and maximum chlorophyll content was recorded in T3 and T4 treatment at different duration which meant high shelf life. Comparatively T3 and $\mathrm{T} 4$ treatment on physiological changes of tomato protracted the tomato shelf life whereas MDA content was minimum and chlorophyll content was maximum.

\section{Based on the above conclusion following recommendations can be made:}

a) For some growth parameter of tomato T4 treatment was best. So it can be used for growth parameter.

b) T3 treatment can be applied on physiological changes of tomato.

c) Further investigation should be carried out to clarify the plant growth and shelf life of tomato.

\section{References}

1. Sekhar L, Prakash BG, Salimath PM, Channayya Hiremath, Sridevi Onteddu, et al. (2010) Implications of heterosis and combining ability among productive Single cross hybrids in tomato. Electron J Plant Breed 1(4): 706-711.

2. Frusciante L, Carli P, Ercolano MR, Rita Pernice, Antonio Di Matteo, et al. (2007) Antioxidant nutritional quality of tomato. Mol Nutr Food Res 51(5): 609-617.

3. Sarker MNI, Ahmad MS, Islam MS, et al. (2020) Potential food safety risk in fruit production from the extensive use of fluorine-containing agrochemicals. Fluoride 53(3): 1-22.

4. Islam MD Il, Rahman A, Sarker MNI, Sazzadur Rahman Sarker, Luo Jianchao, et al (2020) Factors Influencing Rice Farmers' Risk Attitudes and Perceptions in Bangladesh amid Environmental and Climatic Issues. Polish J Environ Stud 30(1): 177-187.

5. Ali MA, Islam MS, Sarker MNI, Bari MA (2015) Study on Biology of Red Pumpkin Beetle in Sweet Gourd Plants. Int J Appl Res J 2(1): 1-4.

6. Martin C, Bassolino L, Zhang Y, Claudia Kiferle, Pierdomenico Perata, et al. (2013) Accumulation of anthocyanins in tomato skin extends shelf life. New Phytol 200(3): 650-655.

7. Shao HB, Chu LY, Lu ZH, Kang CM (2008) Primary antioxidant free radical scavenging and redox signaling pathways in higher plant cells. Int J Biol Sci 4(1): 8-14.

8. Choudhury FK, Rivero RM, Blumwald E, Mittler R (2017) Reactive oxygen species, abiotic stress and stress combination. Plant J 90(5): 856-867.

9. Haider MK, Islam MS, Islam SS, Sarker MNI (2015) Determination of crop coefficient for transplanted Aman rice. Int J Nat Soc Sci 2: 34-40.

10. Chen G, Sui X, Kamruzzaman MM (2019) Agricultural remote sensing image cultivated land extraction technology based on deep learning. Rev la Fac Agron 36: 2199-2209

11. Kamruzzaman MM, He W, Peng X (2019) Performance of relay assisted uplink wireless communication using multi-layered STBC for multiple access channels. Telecommun Syst 71: 309-320.

12. BBS (2014) Statistical Pocketbook. BBS, Dhaka, Bangladesh

13. Islam MS, Ali MA, Sarker MNI (2015) Efficacy of medicinal plants against seed borne fungi of wheat seeds. Int J Nat Soc Sci 2: 48-52.

14. Sarker MNI, Islam MS, Ali MA, Saiful Islam, Hasan Mahmud SM, et al (2019) Promoting digital agriculture through big data for sustainable farm management. Int J Innov Appl Stud 25(4): 1235-1240.

15. Sarker MNI, Yang B, Tingzhi W, Aditi Chakrovorty, Nazmul Huda, et al (2020) Impacts of internal migration on poverty alleviation in Bangladesh. Int Trans J Eng Manag Appl Sci Technol 11: 1-8.

16. Sarker MNI, Peng Y, Yiran C, Shouse RC (2020) Disaster resilience through big data: Way to environmental sustainability. Int J Disaster Risk Reduct 51: 101769

17. Sarker MNI, Yang B, Lv Y, Enamul Huq, Kamruzzaman MM, et al. (2020) Climate Change Adaptation and Resilience through Big Data. Int J Adv Comput Sci Appl 11(3): 533-539.

18. Prodhan AS, Sarker MNI, Sultana A, Islam MS (2017) Knowledge,adoption and attitude on banana cultivation technology of the banana growers of Bangladesh. Int J Hortic Sci Ornam Plants 3(1): 47-52.

19. Decros G, Baldet P, Beauvoit B, Rebecca Stevens, Amélie Flandin, et al (2019) Get the Balance Right: ROS Homeostasis and Redox Signalling in Fruit. Front Plant Sci 10: pp. 1091.

20. Filiz E, Ozyigit II, Saracoglu IA, Mehmet EU, Uger S, et al. (2019) Abiotic stress-induced regulation of antioxidant genes in different Arabidopsis ecotypes: microarray data evaluation. Biotechnol Biotechnol Equip 33(1): 128-143. 
21. Aghdam MS (2013) Role of alternative oxidase in postharvest stress of fruit and vegetables: Chilling injury. African J Biotechnol 12(51): 70097016

22. Wang Y, Ji D, Chen T, Li B, Zhang Z, et al. (2019) Production, signaling, and scavenging mechanisms of reactive oxygen species in fruit-pathogen interactions. Int J Mol Sci 20(12): pp. 2994.

23. Xu Z, Mahmood K, Rothstein SJ (2017) ROS induces anthocyanin production via late biosynthetic genes and anthocyanin deficiency confers the hypersensitivity to ROS-generating stresses in arabidopsis. Plant Cell Physiol 58(8):1364-1377.

24. Sarker MNI, Islam S, Rahman M (2015) Effects of electronic banking on performance of banks in Bangladesh. Int J Appl Res J 1: 28-34.

25. Chen G, Pei Q Kamruzzaman MM (2020) Remote sensing image quality evaluation based on deep support value learning networks. Signal Process Image Commun 83: pp. 115783

26. Islam MS, Sarker MNI, Ali MA (2015) Effect of seed borne fungi on germinating wheat seed and their treatment with chemicals. Int J Nat Soc Sci 2: 28-32.

27. Ghosh DK, Hossain MN, Sarker MNI, Islam S (2020) Effects of landuse changes pattern on tree plantation: Evidence from gher land in Bangladesh. Int J Agric Policy Res 8(3): 55-65. Sarker MNI, Islam MS, Murmu H, Rozario E (2020) Role of Big Data on Digital Farming. Int J Sci Technol Res 9(4): 1222-1225.

28. Das K, Roychoudhury A (2014) Reactive oxygen species (ROS) and response of antioxidants as ROS-scavengers during environmental stress in plants. Front Environ Sci 2: 1-13.

29. Waraich EA, Ahmad R, Halim A, Aziz T (2012) Alleviation of temperature stress by nutrient management in crop plants: A review. J Soil Sci Plant Nutr 12(2): 221-244.

30. Zhang Y, De Stefano R, Robine M, Eugenio Butelli, Katharina Bulling, et al. (2015) Different reactive oxygen species scavenging properties of flavonoids determine their abilities to extend the shelf life of tomato. Plant Physiol 169(3): 1568-1583.

31. Akher SA, Sarker MNI, Naznin S (2018) Salt stress mitigation by salicylic acid in wheat for food security in coastal area of Bangladesh. J Plant Stress Physiol 4: 07-16.

32. Sarker MNI, Wu M, Chanthamith B, Yusufzada Shaheen, Dandan Li, et al. (2019) Big Data Driven Smart Agriculture: Pathway for Sustainable
Development. In: (eds) 2019 2nd International Conference on Artificial Intelligence and Big Data (ICAIBD). IEEE, pp 60-65.

33. Chen G, Wang L, Kamruzzaman MM (2020) Spectral classification of ecological spatial polarization SAR image based on target decomposition algorithm and machine learning. Neural Comput Appl 32(4): 5449-5460.

34. Yu W, Wang L, Zhao R, Jiping S, Zhang S, et al. (2019) Knockout of SIMAPK3 enhances tolerance to heat stress involving ROS homeostasis in tomato plants. BMC Plant Biol 19(1): 1-13

35. Berni R, Luyckx M, Xu X, SylvainLegay, KjellSergeant, et al (2019) Reactive oxygen species and heavy metal stress in plants: Impact on the cell wall and secondary metabolism. Environ Exp Bot 161: 98-106.

36. Sarker MNI, Barman SC, Islam M, Islam R, Amithabh SC,et al. (2017) Role of lemon (Citrus limon) production on livelihoods of rural people in Bangladesh. J Agric Econ Rural Dev 3(1): 167-175.

37. Islam MS, Proshad R, Asadul Haque M, Nazirul Islam Sarker (2020) Assessment of heavy metals in foods around the industrial areas: health hazard inference in Bangladesh. Geocarto Int 35(3): 280-295.

38. Gomes MP, Garcia QS (2013) Reactive oxygen species and seed germination. Biol 68(3): 351-357.

39. Yao GF, Wei ZZ, Li TT, Jun Tang, Zhong-Qin Huang, et al (2018) Modulation of Enhanced Antioxidant Activity by Hydrogen Sulfide Antagonization of Ethylene in Tomato Fruit Ripening. J Agric Food Chem 66(40): 1038010387.

40. Sarker MNI, Azam SMM, Parvin S, Rahman MS (2019) DNA fingerprinting and molecular characterization of Brassica cultivars using RAPD markers. Res J Biotechnol 14(8): 40-44.

41. Mittler R, Vanderauwera S, Gollery M, Van Breusegem F (2004) Reactive oxygen gene network of plants. Trends Plant Sci 9(10): 490-498.

42. Xu Z, Rothstein SJ (2018) ROS-Induced anthocyanin production provides feedback protection by scavenging ROS and maintaining photosynthetic capacity in Arabidopsis. Plant Signal Behav 13(3): e1451708.

43. Islam MS, Khanam MS, Sarker NI (2018) Health risk assessment of metals transfer from soil to the edible part of some vegetables grown in Patuakhali province of Bangladesh. Arch Agric Environ Sci 3(2): 187197.
This work is licensed under Creative Commons Attribution 4.0 License

To Submit Your Article Click Here: Submit Article

DOI: $10.32474 / C I A C R .2020 .09 .000305$

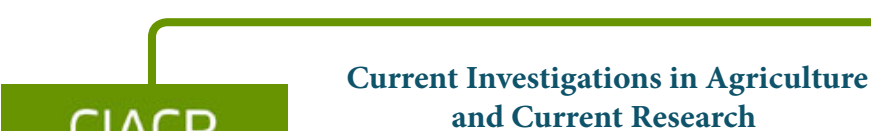
and Current Research

\section{Assets of Publishing with us}

- Global archiving of articles

- Immediate, unrestricted online access

- Rigorous Peer Review Process

- Authors Retain Copyrights

- Unique DOI for all articles 